\title{
CONTEMPORARY TWO-STOREY CHURCHES - ACOUSTIC INVESTIGATIONS
}

\author{
Anna SYGULSKA \\ Faculty of Architecture, Poznań University of Technology, \\ Ul. Nieszawska 13 C, 61-021 Poznań, Poland \\ E-mail: anna.sygulska@put.poznan.pl
}

Received 02 February 2015; accepted 21 May 2015

\begin{abstract}
The paper discusses the idea of two-storey churches, with insight into socio-political conditions which influenced their construction. The analysis of the issue was carried out on the basis of investigations in five two-storey churches in Poznań. The churches under investigation were: Visitation of Blessed Virgin Mary Church, Christ the King Church, Our Lady of Częstochowa Church, St. Lawrence Church, and Christ the Redeemer Church. In total, ten interiors were examined. The churches were erected in the late $70 \mathrm{~s}$ and early $80 \mathrm{~s}$ of the 20th century. The acoustic conditions were analyzed in terms of cubature, the shape of the interior and finishes. The upper and lower churches were compared within one building; the investigation also involved comparing the churches against each other. Moreover, functionality of the buildings was analyzed, which included aspects of acoustic as well as architectural functionality.
\end{abstract}

Keywords: two-storey churches, contemporary churches, church acoustics, acoustic investigations in churches.

\section{Introduction}

The paper addresses the issue of contemporary twostorey churches in Poznan. The analysis of the issue was carried out on the basis of investigations in five two-storey churches in Poznań. The churches under investigation were: Christ the King Church (Figs la, b), Christ the Redeemer Church (Figs 2a, b), Our Lady of Częstochowa Church (Figs 3a, b), St. Lawrence Church (Figs 4a, b), and Visitation of Blessed Virgin Mary Church (Figs 5a, b). In total, ten interiors were examined. The churches were erected in the late $70 \mathrm{~s}$ and early 80 s of the 20 th century.

The issue of acoustics in churches is complex, as church interiors must promote functions of extreme acoustic requirements. Intelligibility of speech is crucial, being the basis of the Catholic liturgy. However, the organ is inherent in the liturgy, too. For organ music, the recommended acoustic parameters are entirely different from those for speech. Two-storey churches are particularly interesting in terms of acoustics because they are composed of two interiors with different acoustic properties. As a rule, the upper church is usually bigger and more decorative.
The number of publications on the issue of acoustics in churches is not as extensive as publications on concert and opera halls. Yet, the subject is raised more and more frequently; a few of chosen publications are discussed below. In literature dealing with the issues of church acoustics, there are books like (Wróblewska, Kulowski 2007) and (Engel et al. 2007). The issues of religious building of different faith were discussed in (Kleiner et al. 2010). The study (Martellotta et al. 2009) presents a mode of taking acoustical measurements. The article is actually a guidebook giving instructions on taking acoustical measurements in churches. The issue was broadly discussed, including modes of measurement for buildings with longitudinal or central plan view. The article (Queiroz de Sant'Ana, Trombetta Zannin 2011) discusses an investigation of contemporary Church of Sao Carlom Borromen, it is an in-depth acoustic study of a church. The issue of reverberance was described, among others, in the papers mentioned below. The paper (Kosała, Kamisiński 2011) discusses the issue of excessive reverberance on the example of the St. Paul's 
Church in Bochnia. On the basis of measurements and acoustic simulations, acoustic treatment was suggested. Another study (Engel, Kosała 2005) presents a new method of acoustic assessment of religious buildings by means of the global index of the acoustic quality. The paper describes the application of the indexing method for five Roman Catholic churches. Acoustics of chapels of the Church of the Holy Trinity in Fatima were discussed in (Carvalho, Nascimento 2011). Acoustic measurements were taken and acoustic properties of the chapels were compared with typical religious buildings in Portugal. The paper (Carvalho et al. 2012) describes the issue of too long reverberation time and poor intelligibility of speech in two churches from the first half of the 20th century. After investigations, acoustic treatment was suggested. The article (Buenó et al. 2012) discusses issues of the modern church of Santa Ana in Moralatz in Madrid. The church underwent investigations and acoustic treatment was suggested to diminish the too long reverberation time. Acoustic treatment of two newly built churches in Croatia was discussed in (Horvat et al. 2011). Results of the investigations were presented for each stage of the applied acoustic treatment, while a study (Tavares et al. 2008) shows measurements taken in Old Goa's Capela do Monte, which constitutes a new approach to acoustic research in churches. The results are used to describe prayer mood of a given interior. The article (Martellotta et al. 2011) discusses the issue of sound absorption by worshippers in pews. The research included both laboratory and in-situ measurements in six churches. The paper (Sendra et al. 1999) discusses issues of acoustics in churches and describes acoustic properties of churches from early Christian times to late Baroque. Next, the study provides characteristics of the Mudejar-Gothic church, typical of the Seville area, with a timber roof. The paper also includes three rehabilitation projects in churches, in which the authors took part. The paper (Alonso 2014) presents computer simulations of the Seville Cathedral which involved examination how decoration of the interior on the occasion of various festive or commemorative events (such as canonisation of King San Fernando in 1671) changed the acoustics. The simulation was carried out by means of the CATT-Acoustic software. The article (Álvarez-Morales 2014) discusses the Cathedral of Malaga as the subject of an experimental methodology for cathedral churches. The presented issues particularly refer to spaces of big religious buildings consisting of numerous subspaces, such as a nave, a choir or a retrochoir. Also, as religious buildings are used for concert purposes, too, the publication (Magrini,
Ricciardi 2003) is an interesting work. Chosen churches in Geneva were under investigation. The interiors were examined for their acoustic adaptation for the needs of a concert.

\section{The idea of two-storey church}

The idea of the two-storey church consists in designing two interiors to hold Holy Mass within one building. The building has two storeys, with a so-called upper church and a lower church. It is assumed that the upper church is bigger and thus considered the main church, while its lower counterpart often has a size of a major chapel. It is also quite common to see a Catholic church with two interiors for religious purposes with one main hall and an additional chapel where it is possible to hold mass. However, what differentiates a twostorey church from the aforementioned building is architectural solutions and its functional layout. Namely, a two-storey church has two separate and independent entrances, often in two different elevations. This allows the interiors to be used simultaneously, and the flow of people does not disturb the course of Holy Mass. Usually, the front elevation has a door leading to the upper church, while the side or rear wall has a door leading to the lower church. It may happen that both entrances are in the main elevation but the independence of the lower and upper hall remains clear and obvious. Usually, a church with the main hall along with an additional chapel has no independent access to the chapel, that is, it either has one common entrance leading to a vestibule or the chapel can be entered from the main hall. If the chapel happens to have a separate door, it is often a small interior on the same level as the main hall of the church.

Two-storey churches are built for different purposes. One of the reasons was the socio-economical situation in Poland in the late 1970s and early 1980s, when it was difficult to obtain a permission to erect a church. In contrast, there was an urgent need for religious buildings in newly built housing estates. When the project of Visitation of Blessed Virgin Mary Church obtained such a permission, a vast building in the form of a twostorey church was erected as it was widely known that yet another permission for another church would not be feasible. For many years, the church served its purpose to dwellers of a few neighbouring housing estates.

The analyzed churches have single-space interiors. Christ the Redeemer Church has arcades on either side and in the rear, also, Our Lady of Częstochowa Church has a gallery on the side walls and on the rear wall. However, the percentage rate of the arcades and the gallery to the cubature is low in both churches. 


\section{Description of the investigations}

The acoustic investigations were conducted by means of an omnidirectional sound source, a SVAN 945A Sound Level Meter and the DIRAC programme. The e-sweep signal was generated and $R T, T s, C 80$ and C50 were measured. The Brüel \& Kjær ZE-0948 USB Audio Interface was used. A sound source was located in front of the altar at the height of $1.5 \mathrm{~m}$. Measuring points were evenly distributed in the nave. Depending on the area of a given church, the number of measuring points oscillated between 6 and 40 . The analysis covered parameters which are regarded in literature as one of basic parameters to evaluate acoustic properties of religious interiors. The investigated acoustic parameters were compared with recommendations (Wróblewska, Kulowski, 2007); (Everest, Pohlmann, 2009). The examined churches including cubatures of upper and lower churches are shown and compared in Table 1.

Table 1. Investigated churches (created by the author)

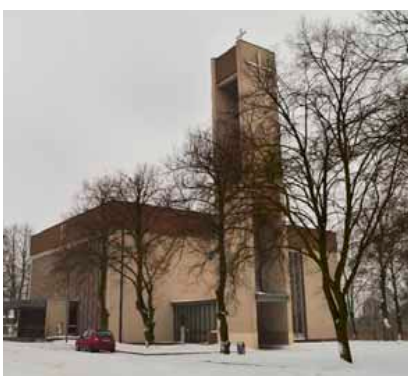

Christ the King church (Figs $1 \mathrm{a}$ and 1b)

1a. Upper church - cubature $4600 \mathrm{~m}^{3}$

1b. Lower church - cubature $315 \mathrm{~m}^{3}$
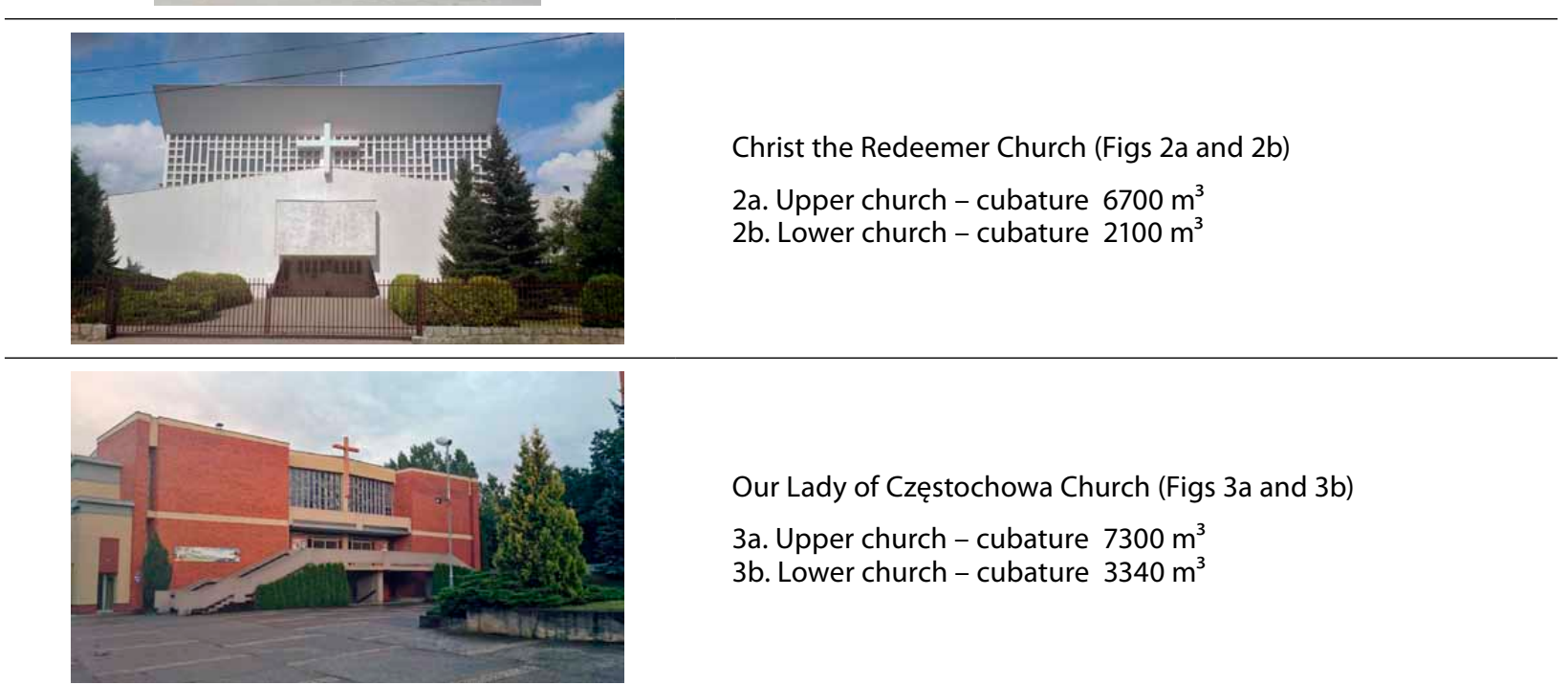

Our Lady of Częstochowa Church (Figs 3a and 3b)

3a. Upper church - cubature $7300 \mathrm{~m}^{3}$

3b. Lower church - cubature $3340 \mathrm{~m}^{3}$

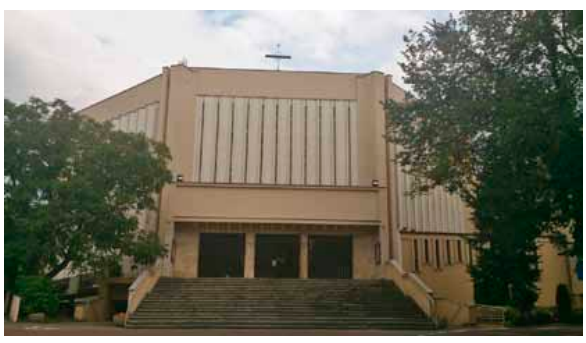

St. Lawrence Church (Figs 4a and 4b)

4a. Upper church - cubature $7500 \mathrm{~m}^{3}$ 4b. Lower church - cubature $1340 \mathrm{~m}^{3}$

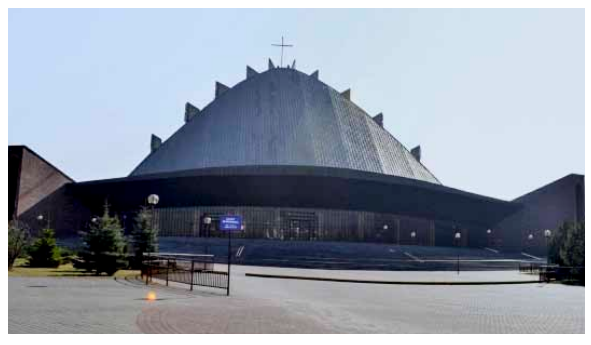

Visitation of Blessed Virgin Mary Church (Figs 5a and 5b)

5a. Upper church - cubature $19000 \mathrm{~m}^{3}$ 5b. Lower church - cubature $4800 \mathrm{~m}^{3}$ 
a)

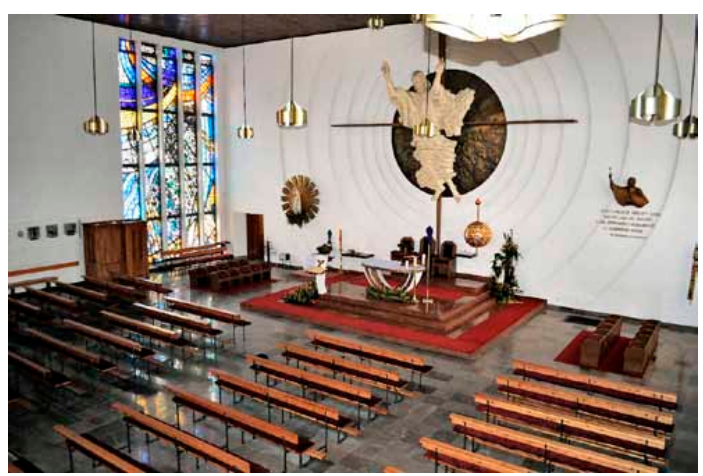

b)

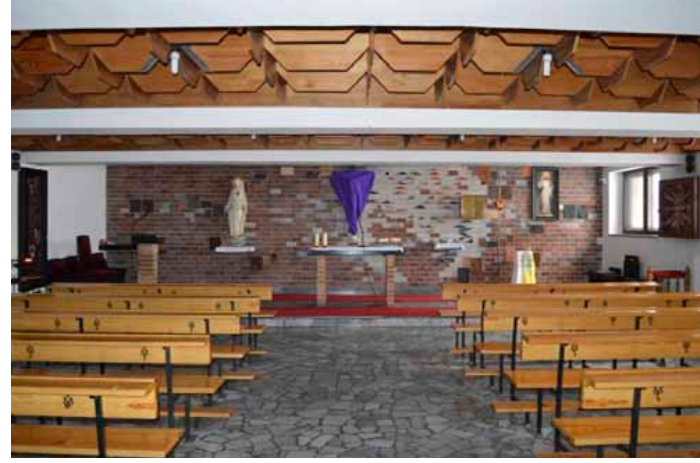

Fig. 1. Christ the King: a - upper church, b-lower church (photo by author)

a)

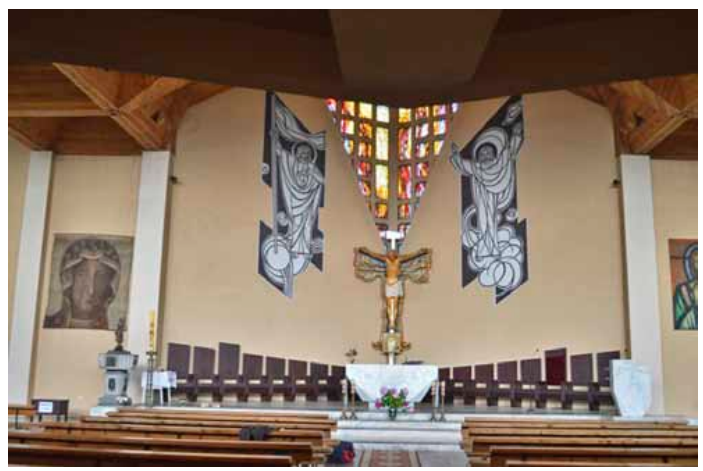

b)

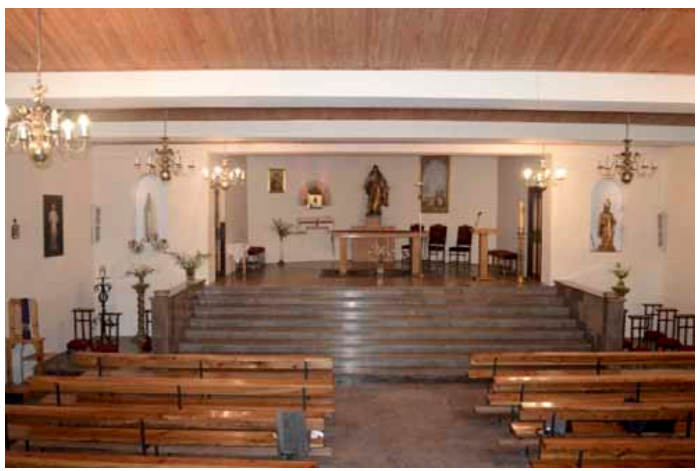

Fig. 2. Christ the Redeemer Church: $a$ - upper church, b - lower church (photo by author)

a)

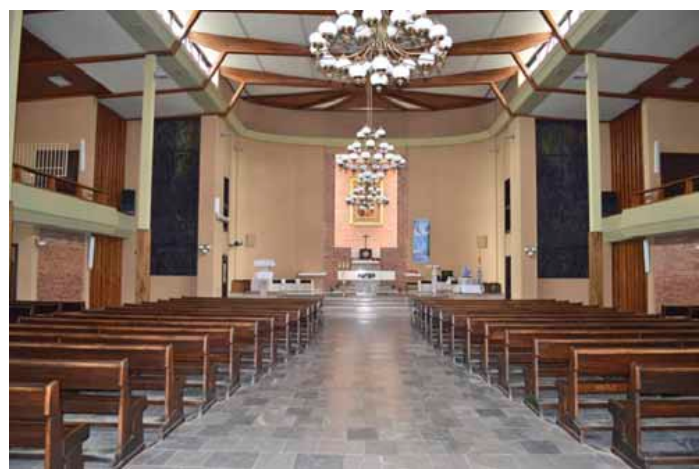

b)

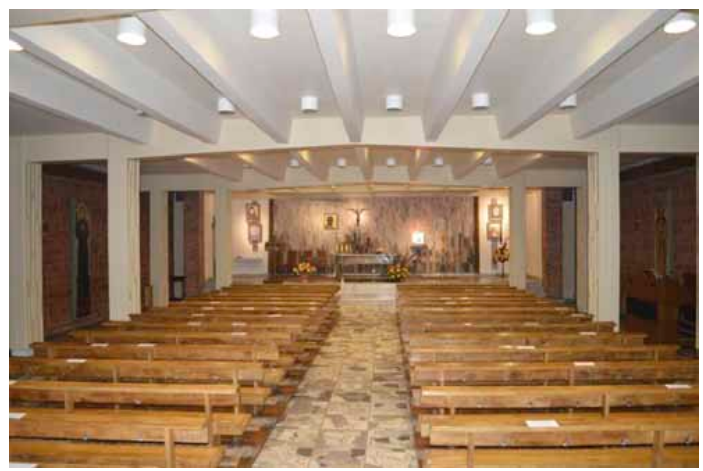

Fig. 3. Our Lady of Częstochowa Church: a - upper church, b - lower church (photo by author)

a)

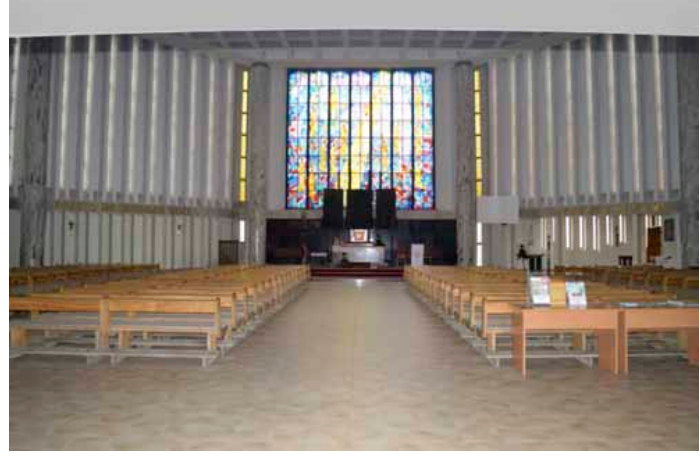

b)

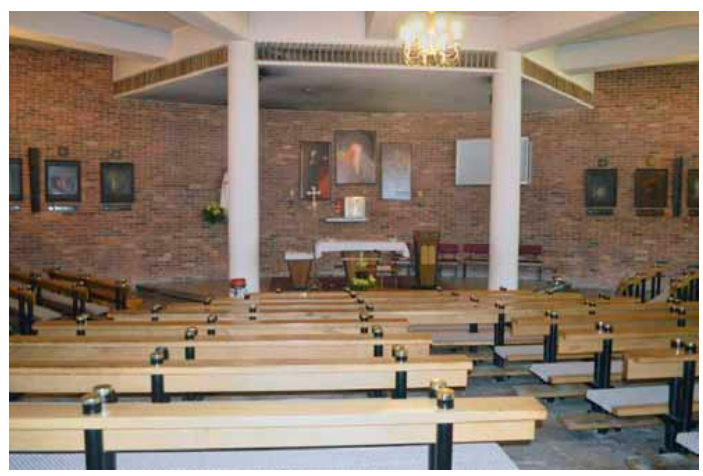

Fig. 4. St. Lawrence Church: a - upper church, b - lower church (photo by author) 
a)

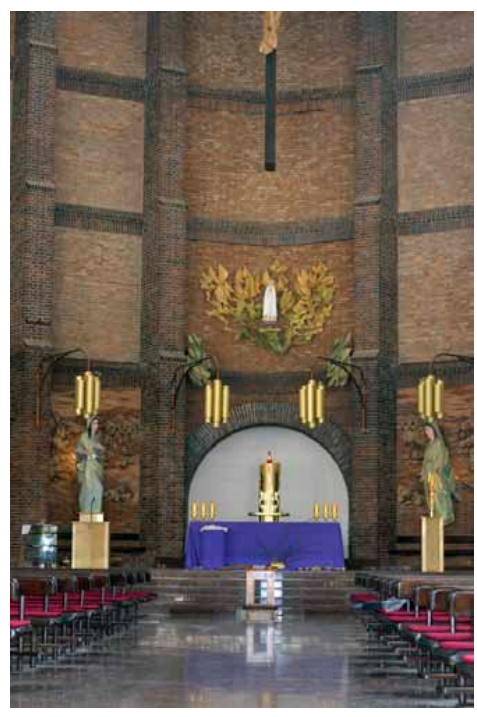

b)

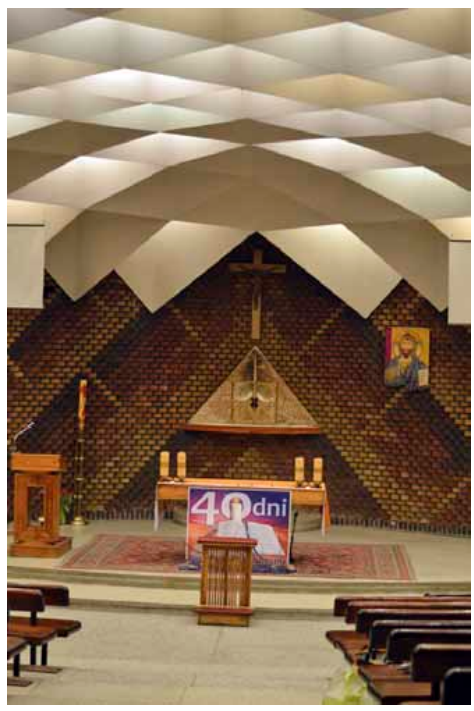

Fig. 5. Visitation of Blessed Virgin Mary Church: a - upper church, b - lower church (photo by author)

\section{Results of the investigations}

Results of the investigations were compared with recommendations available in literature.

Figure 6 depicts a graph illustrating recommended reverberation time for churches depending on their cubature (Everest, Pohlmann 2009). Dark grey colour represents recommended reverberation time for churches with frequent organ music performances. Light grey colour represents reverberation time for churches where speech is dominant.

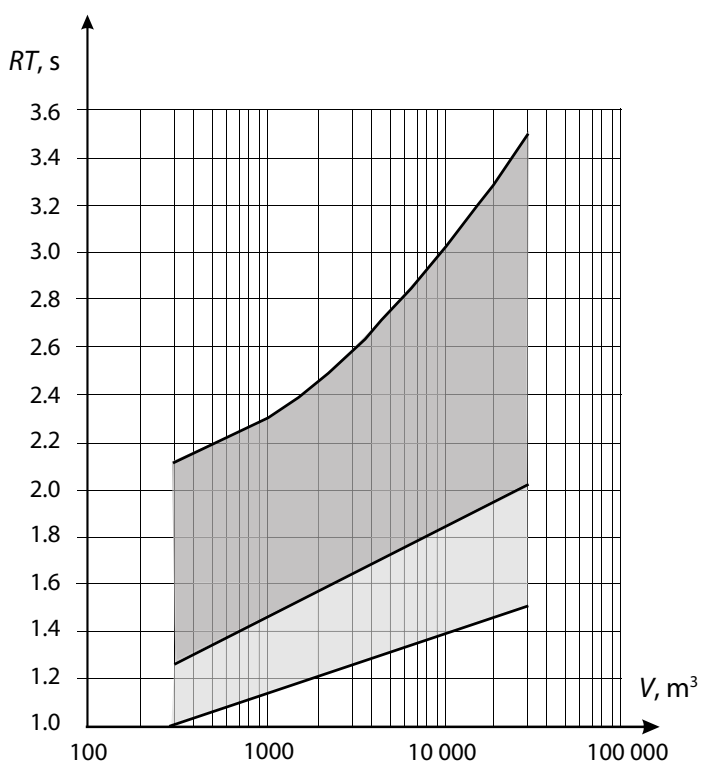

Fig. 6. Range of optimum reverberation time for churches (Everest, Pohlmann 2009)
Table 2 shows the comparison of reverberation time RT and centre time Ts. In addition, reverberation time is shown in a frequency function, separately for upper churches (Fig. 7) and separately for lower churches (Fig. 8).

Lower churches have smaller cubatures, the result of which is that reverberation time meets the recommendations or is slightly exceeded. Church (5b) is an exception as its cubature is equivalent to a middlesize church. For upper churches, reverberation time fits in with the recommended values only in the case of church 2a. It is caused by the shape and construction of the ceiling, which increases sound absorption. Churches (5a) and (4a) are the most problematic as reverberation time and other parameters considerably exceed recommended values. Results of the investigations confirm subjective perception of excessive reverberation in these churches. Their interiors have such high levels of reverberation noise that the reception of Holy Mass is disturbed and speech is unintelligible. In these cases, acoustic treatment would be necessary.

To assess the clarity of music sound, centre time $T s$ is applied; $T s$ is the center of gravity along the time axis of the squared impulse response (Barron 2005). The measured parameter $T s$ reaches the best values in church (2a). The results show that the interior meets requirements for organ music performances. Apart from the favourable values of parameter $T s$, the church has a cubature ensuring good organ sound. 
Table 2. Comparison of reverberation time and centre time (created by the author)

\begin{tabular}{|c|c|c|c|c|c|}
\hline \multirow{2}{*}{ Name of the church } & \multicolumn{3}{|c|}{$R T, \mathrm{~s}$} & \multicolumn{2}{|r|}{$T s, \mathrm{~ms}$} \\
\hline & mean & $500-1000 \mathrm{~Hz}$ & recommended mean & mean & recommended mean \\
\hline \multicolumn{6}{|l|}{ Christ the King church } \\
\hline 1a. Upper church & 3.3 & 3.8 & $1.3-2.7$ & 248 & $\begin{array}{l}60-100 \\
\text { organ music to } 180\end{array}$ \\
\hline 1b. Lower church & 1.6 & 1.6 & $1.0-2.1$ & 135 & $\begin{array}{l}60-100 \\
\text { organ music to } 180\end{array}$ \\
\hline \multicolumn{6}{|c|}{ Christ the Redeemer Church } \\
\hline 2a. Upper church & 2.5 & 2.6 & $1.3-2.9$ & 175 & $\begin{array}{l}70-120 \\
\text { organ music to } 180\end{array}$ \\
\hline 2b. Lower church & 2.2 & 2.5 & $1.2-2.5$ & 175 & $\begin{array}{l}60-100 \\
\text { organ music to } 180\end{array}$ \\
\hline \multicolumn{6}{|c|}{ Our Lady of Częstochowa Church } \\
\hline 3a. Upper church & 3.6 & 4.2 & $1.3-2.9$ & 255 & $\begin{array}{l}70-120 \\
\text { organ music to } 180\end{array}$ \\
\hline 3b. Lower church & 2.7 & 2.9 & $1.2-2.6$ & 202 & $\begin{array}{l}60-100 \\
\text { organ music to } 180\end{array}$ \\
\hline \multicolumn{6}{|l|}{ St. Lawrence Church } \\
\hline 4a. Upper church & 5.5 & 6.2 & $1.3-2.9$ & 376 & $\begin{array}{l}70-120 \\
\text { organ music to } 180\end{array}$ \\
\hline 4b. Lower church & 3.3 & 3.2 & $1.1-2.3$ & 216 & $\begin{array}{l}60-100 \\
\text { organ music to } 180\end{array}$ \\
\hline \multicolumn{6}{|c|}{ Visitation of Blessed Virgin Mary Church } \\
\hline 5a. Upper church & 5.9 & 7.1 & $1.5-3.3$ & 410 & $120-180$ \\
\hline 5b. Lower church & 3.8 & 4.1 & $1.3-2.7$ & 298 & $\begin{array}{l}60-100 \\
\text { organ music to } 180\end{array}$ \\
\hline
\end{tabular}

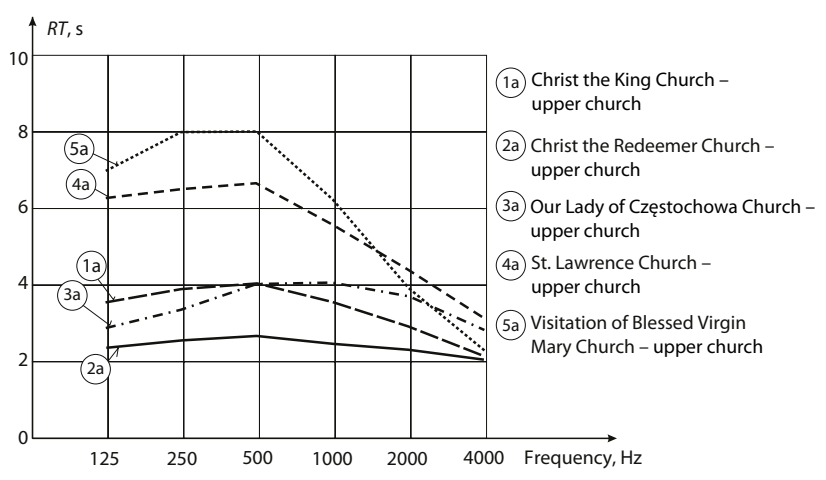

Fig. 7. Frequency characteristics of averaged reverberation time in the upper churches (created by the author)

Table 3 shows results of measurements of clarity index C80. This parameter is applied to determine quality of the music sound. In the logarithmic scale, it describes the ratio of the energy of the sound reaching the measuring point within first $80 \mathrm{~ms}$ to the energy of the sound reaching it after $80 \mathrm{~ms}$ (Everest, Pohlmann 2009). According to recommendations given in literature (Wróblewska, Kulowski 2007), C80 was averaged for $0.5,1,2 \mathrm{kHz}$.

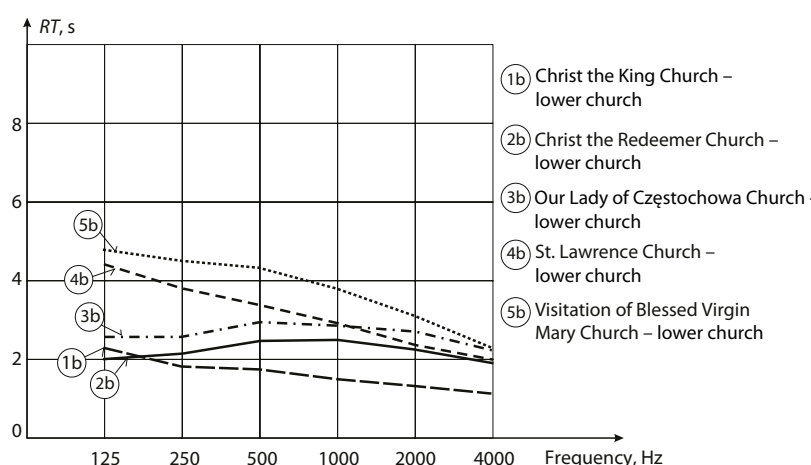

Fig. 8. Frequency characteristics of averaged reverberation time in the lower churches (created by the author)

Apart from church (4a), the value of clarity index C80 is suitable for organ music in upper churches. As for lower churches with a smaller cubature, it is assumed that the electronic organ will be used. For this type of instrument, the value of the index C80 is exceeded in comparison with the recommendations. The case of church (5b) is particularly problematic as the values of the index $C 80$ considerably exceed 
Table 3. Comparison of clarity index C80 (created by the author)

\begin{tabular}{|c|c|c|c|c|c|}
\hline \multirow[b]{2}{*}{ Name of the church } & \multicolumn{5}{|c|}{$\mathrm{C} 80, \mathrm{~dB}$} \\
\hline & first row & recommended & last row & recommended & $\begin{array}{c}\text { general } \\
\text { recommendations }\end{array}$ \\
\hline \multicolumn{6}{|l|}{ Christ the King church } \\
\hline 1a. Upper church & $\begin{array}{l}-2.0 \\
-4.8 \\
-6.2\end{array}$ & $>0$ & $\begin{array}{l}-5.3 \\
-6.0 \\
-5.3\end{array}$ & $>2$ & $\begin{array}{l}\text { symphonic and } \\
\text { oratorio music }-3 \text { to } 6 \\
\text { organ music }<-3\end{array}$ \\
\hline 1b. Lower church & $\begin{array}{r}-0.7 \\
0.3\end{array}$ & 3 to 8 & $\begin{array}{l}-1.7 \\
-1.6\end{array}$ & - & $\begin{array}{l}>6 \\
\text { electronic organ }\end{array}$ \\
\hline \multicolumn{6}{|c|}{ Christ the Redeemer Church } \\
\hline 2a. Upper church & $\begin{array}{l}-0.4 \\
-0.5 \\
-2.6 \\
-3.3\end{array}$ & $>0$ & $\begin{array}{l}-4.1 \\
-2.5 \\
-3.5 \\
-4.7\end{array}$ & $>2$ & $\begin{array}{l}\text { symphonic and } \\
\text { oratorio music }-3 \text { to } 6\end{array}$ \\
\hline 2b. Lower church & $\begin{array}{l}-2.2 \\
-2.4\end{array}$ & 3 to 8 & $\begin{array}{l}-5.1 \\
-6.1\end{array}$ & - & $\begin{array}{l}>6 \\
\text { electronic organ }\end{array}$ \\
\hline \multicolumn{6}{|c|}{ Our Lady of Częstochowa Church } \\
\hline 3a. Upper church & $\begin{array}{l}-1.4 \\
-1.3\end{array}$ & $>0$ & $\begin{array}{l}-6.5 \\
-5.8 \\
-6.6 \\
-7.7\end{array}$ & $>2$ & $\begin{array}{l}\text { symphonic and } \\
\text { oratorio music }-3 \text { to } 6\end{array}$ \\
\hline 3b. Lower church & $\begin{array}{l}-0.6 \\
-1.2\end{array}$ & 3 to 8 & $\begin{array}{l}-5.7 \\
-6.1\end{array}$ & - & $\begin{array}{l}>6 \\
\text { electronic organ }\end{array}$ \\
\hline \multicolumn{6}{|l|}{ St. Lawrence Church } \\
\hline 4a. Upper church & $\begin{array}{l}-2.5 \\
-4.4 \\
-5.5 \\
-6.3\end{array}$ & $>0$ & $\begin{array}{l}-6.4 \\
-7.5 \\
-8.2 \\
-8.3\end{array}$ & $>2$ & $\begin{array}{l}\text { symphonic and } \\
\text { oratorio music }-3 \text { to } 6\end{array}$ \\
\hline 4b. Lower church & $\begin{array}{l}-0.36 \\
-0.68 \\
-0.65\end{array}$ & 3 to 8 & $\begin{array}{l}-3.1 \\
-2.8 \\
-2.3 \\
-3.2\end{array}$ & - & $\begin{array}{l}>6 \\
\text { electronic organ }\end{array}$ \\
\hline \multicolumn{6}{|c|}{ Visitation of Blessed Virgin Mary Church } \\
\hline 5a. Upper church & $\begin{array}{l}-2.6 \\
-4.5 \\
-8.2\end{array}$ & $>0$ & $\begin{array}{r}-5.9 \\
-7.3 \\
-8\end{array}$ & -1 to 1 & $\begin{array}{l}\text { organ music }-8 \text { to }-3 \\
\text { oratorio music }-3 \text { to } 6\end{array}$ \\
\hline 5b. Lower church & $\begin{array}{l}-1.8 \\
-2.3 \\
-3.3\end{array}$ & $>0$ & $\begin{array}{l}-17.3 \\
-18.6 \\
-17.9\end{array}$ & $>2$ & $\begin{array}{l}\text { symphonic and } \\
\text { oratorio music }-3 \text { to } 6\end{array}$ \\
\hline
\end{tabular}

recommended values in the rear pews. It is caused by the shape of the interior, because the height abruptly decreases in the rear pews.

Table 4 presents results of measurements of clarity index C50. By analogy, the index is defined like C80. The measurements allow to calculate the weighted value of clarity index C50. Octave bands $0.5,1,2,4 \mathrm{kHz}$ are multiplied by the weighting factor equal to $0.15,0.25$, 0.35 and 0.25 for each band respectively; thus obtained results are added. The index $C 50$, like index $C 80$, is particularly unfavorable in church (5b). The values which considerably vary from the recommendations occur in the rear pews.

\section{Conclusions}

In the analyzed buildings, contemporary construction solutions were applied. Load bearing elements of the ceiling and roof construction were made either of monolithic reinforced concrete or by means of steel trusses. Such solutions enable covering of considerable spans without application of intermediate supports. This has a large influence on the acoustics of the interior as the lack of subspaces affects excessive reverberation.

In the case of single-interior churches, with big cubatures (about $5000 \mathrm{~m}^{3}$ and more) and finished with 
Table 4. Comparison of clarity index C50 (created by the author)

\begin{tabular}{|c|c|c|c|}
\hline \multirow{2}{*}{ Name of the church } & \multicolumn{3}{|c|}{$\mathrm{C} 50, \mathrm{~dB}$} \\
\hline & mean & range of variation & recommended \\
\hline \multicolumn{4}{|l|}{ Christ the King church } \\
\hline 1a. Upper church & -7.9 & -2.9 to -12 & $>-2$ \\
\hline 1b. Lower church & -3.7 & -2.7 to -5.5 & $>-2$ \\
\hline \multicolumn{4}{|c|}{ Christ the Redeemer Church } \\
\hline 2a. Upper church & -5 & -2.6 to -6.9 & $>-2$ \\
\hline 2b. Lower church & -5.6 & -4.2 to -8.1 & $>-2$ \\
\hline \multicolumn{4}{|c|}{ Our Lady of Częstochowa Church } \\
\hline 3a. Upper church & -7.1 & -2.4 to -11 & $>-2$ \\
\hline 3b. Lower church & -5.8 & -2.3 to -7.9 & $>-2$ \\
\hline \multicolumn{4}{|l|}{ St. Lawrence Church } \\
\hline 4a. Upper church & -7.86 & -2.8 to -9.8 & $>-2$ \\
\hline 4b. Lower church & -3.4 & -1.3 to -4.6 & $>-2$ \\
\hline \multicolumn{4}{|c|}{ Visitation of Blessed Virgin Mary Church } \\
\hline 5a. Upper church & -8.6 & -2 to -13 & $>-2$ \\
\hline 5b. Lower church & -15.4 & -3.8 to -41 & $>-2$ \\
\hline
\end{tabular}

materials with a low absorption coefficient, too long reverberation time can be expected and, in result, unfavourable acoustic conditions may occur. In the examined churches, the finishes are typical of contemporary religious architecture, i.e. smooth walls covered in lime-cement plaster or clinker bricks, along with numerous glazing windows.

In the majority of cases, the examined lower churches have the recommended reverberation time despite application of sound reflective finishes. The interiors have fairly small cubature, so omission of the acoustic aspect does not cause major problems.

The investigations showed that upper churches i.e. St. Lawrence Church (4a) and Visitation of Blessed Virgin Mary Church (5a) are particularly problematic. The shape of the church (4a) is a regular octagon. The floor is covered with marble, which is a solid material and the absorption coefficient is close to zero. Most of the interior is made of reinforced concrete, which has low acoustic absorption properties. In the wall behind the altar there is a vast stained glass window. The remaining walls have glazings in the form of narrow strips. The reinforced concrete coffered ceiling is massive and solid. Both the walls and the ceiling are textured, which promotes sound diffusion in the interior. However, the applied materials and the vast space result in considerably exceeded reverberation time amounting to about $6 \mathrm{~s}$, while the recommended value should not exceed 3 s. Our Lady of Częstochowa Church (3a) is similar to the church (4a) in terms of the cubature, but it has far better acoustic properties, which is the result of substantially bigger spatial variation. The interior is rectangular, with subspaces in the form of galleries on the side walls and the rear wall. In addition, the range of the applied material is wider: there are carton-gypsum boards constituting the ceiling, which is fixed to the load-bearing structure of the roof. Also, wooden panelling was applied; it was fixed to the side parts of the ceiling and on a few parts of the side walls. Reverberation time in the church amounts to about $4 \mathrm{~s}$.

The church (5a) is considerably bigger from the other churches. The roof has a steel load-bearing structure. The surface of the ceiling is finished with gypsum lime plaster. The ceiling is concave; its area exceeds the area of the plan view of the church. The walls are made of brick. Brick pilasters are evenly distributed on the wall of the presbytery and the side walls. There are glazings inside, especially on the rear wall. The applied pilasters and zigzag shape of the ceiling affect sound diffusion in the interior. In terms of its cubature, the church belongs to the category of the biggest churches (Wróblewska, Kulowski 2007). Such churches often have a high-class organ, and their interiors are often used for concerts. Currently, the discussed church does not have a concert organ. The reverberation time is big and amounts to about $7 \mathrm{~s}$.

When designing a church with a big cubature, it is necessary to design the interior with acoustic requirements in mind. Otherwise, the interior will not properly serve its liturgical purpose, i.e. speech. Besides, reverbe- 
ration noise occurring in such interiors creates unfavourable acoustic atmosphere. Correction of acoustic defects after the erection of the church causes problems and it is difficult to realize because of high costs.

When erecting a new big church, it is advisable to opt for a two-storey one. The upper church is then designed to hold liturgy on Sundays and holidays when a high number of participants is expected. The lower church is used to hold Holy Mass on weekdays with a small number of participants. In addition, with the climate in this part of Europe in mind, maintenance costs of a two-storey church in winter are lower.

\section{Acknowledgements}

The financial support within the grant MNiSzW 10/01/ DSPB/0240 is kindly acknowledged.

\section{References}

Alonso A.; Sendra J. J.; Suárez R. 2014. Sound space reconstruction in the cathedral of Seville for major feasts celebrated around the main chancel, in Proceedings of Forum Acusticum, 7-12 September 2014, Krakow, Poland.

Álvarez-Morales L.; Zamarreño T.; Girón S.; Galindo M. 2014. A methodology for the study of the acoustic environment of Catholic cathedrals: application to the Cathedral of Malaga, Building and Environment 72: 102-115.

Barron, M. 2005. Auditorium acoustics and architectural design, New York: Taylor \& Francis, London.

Buenó A. M.; León A. L.; Galindo M. 2012. Acoustic rehabilitation of the Church of Santa Ana in Moratalaz, Madrid, Archives of Acoustics 37(4): 435-446.

Carvalho A. P. O.; Cruz M. T.; Pereira G. C. G. 2012. Acoustic rehabilitation of middle twentieth century Portuguese churches, in ICSV, 08-12 July 2012, Vilnius, Lithuania.

Carvalho, A. P. O.; Nascimento B. F. O. 2011. Acoustical characterization of the underground chapels of the new Holy Trinity church in the Fatima shrine, in Proceedings of Forum Acusticum, 26 June - 1 July 2011, Aalborg, Denmark. 1429-1434.

Engel, Z.; Engel, J.; Kosała, K.; Sadowski, J. 2007. Podstawy akustyki obiektów sakralnych. Kraków: ITE (in Polish).

Engel, Z.; Kosała, K. 2005. Acoustic properties of the selected churches in Poland, Mechanics 24(3): 173-181.

Everest, F. A.; Pohlmann, K. C. 2009. Master handbook of acoustics. $5^{\text {th }}$ ed. USA: Mc Graw Hill.

Horvat, M.; Domitrovic, H.; Jambrosic, K. 2011. The improvement of acoustic situation in two modern churches, in Proceedings of Forum Acusticum, 26 June - 1 July 2011, Aalborg, Denmark. 1439-1444.

Kleiner, M.; Klepper, D. L.; Torres R. R. 2010. Worship space acoustics. J. Ross Publishing.

Kosała, K.; Kamisiński, T. 2011. Akustyka wielofunkcyjna wnętrz sakralnych. Czasopismo Techniczne/Politechnika Krakowska, Seria Architektura. Zeszyt 11: 115-122.

Magrini, A; Ricciardi, P. 2003. Churches as auditoria: analysis of acoustical parameters for a better understanding of sound quality, Building Acoustics 10(2): 135-158.
Martellotta, F.; Cirillo, E.; Carbonari, A.; Ricciardi, P. 2009. Guidelines for acoustical measurements in churches, Applied Acoustics 70: 378-388.

Martellotta, F.; Della Crociata S., D’Alba M. 2011. On site validation of sound absorption measurements of occupied pews, Applied Acoustics 72: 923-933.

Queiroz de Sant'Ana, D; Trombetta Zannin, P. H. 2011. Acoustic evaluation of a contemporary church based on in situ measurements of reverberation time, definition, and computer-predicted speech transmission index, Building and Environment 46: 511-517.

Sendra J. J.; Zamarreño T.; Navarro J. 1999. Acoustics in churches. Computational acoustics in architecture. Southampton: WIT Press, 133-177.

Tavares, M. A. P.; Rajagopalan S.; Sharma S. J.; Carvalho, A. P. O. 2008. Acoustic characterization of worship ambience in catholic churches - old Goa's Capela do Monte, in Inter Noise 2008, 26-29 October 2008, Shanghai, China.

Wróblewska D.; Kulowski A. 2007. Czynniki akustyki w architektonicznym projektowaniu kościołów. Gdańsk: Wydawnictwo Politechniki Gdańskiej (in Polish).

\section{ANNA SYGULSKA}

Dr in Engineering Architecture, Faculty of Architecture, Poznań University of Technology, Ul. Nieszawska 13 C, 61-021 Poznań, Poland. E-mail: anna.sygulska@put.poznan.pl

Her scientific research involves architectural acoustics. The focus of the research area is issues of acoustics of concert halls, opera houses and churches. Her studies are synthesis of issues on the cusp of two scientific fields - architecture and acoustics. 